Going Native 



\section{Going Native Indians in the American Cultural Imagination}

SHARI M HUHNDORF

Cornell University Press Ithaca and London 


\section{Copyright 102001 by Cornell University}

All rights reserved. Except for brief quotations in a review, this book, or parts thereof, must not be reproduced in any form without permission in writing from the publisher. For information, address Cornell University Press, Sage House, 512 East State Street, Ithaca, New York $1485^{\circ}$.

First published 2001 by Cornell University Press

First printing, Cornell Paperbacks, 2001

Printed in the United States of America

Library of Congress Cataloging-in-Publication Data

Huhndorf, Shari M. (Shari Michelle), 1965-

Going native : Indians in the American cultural imagination / Shari M. Huhndorf. p. $\mathrm{cm}$.

Includes bibliographical references and index.

ISBN 978-o-8014-8695-1 (pbk. : alk. paper)

I. Indians of North America-Public opinion. 2. Public opinion-United States.

3. Nationalism-United States. 4. Indians in literature I. Title.

E98.P99 $\mathrm{H}_{5} 2001$

$973.04 ' 97-\mathrm{dc2}$ ।

oo-o । 08 । 4

Cornell University Press strives to use environmentally responsible suppliers and materials to the fullest extent possible in the publishing of its books. Such materials include vegetable-based, low-VOC inks and acid-free papers that are recycled, totally chlorine-free, or partly composed of nonwood fibers. For further information, visit our website at www.cornellpress.cornell.edu.

Paperback printing $\quad$ 10 987654 
For my parents, Roy and Charlene Huhndorf, and my sister, Charlsie Huhndorf Arend 

The Indian Wars have never ended in the Americas.

-Leslie Marmon Silko, Almanac of the Dead

Indians, the original possessors of the land, seem to haunt the collective unconscious of the white man and to the degree that one can identify the conflicting images of the Indian which stalk the white man's waking perceptions of the world one can outline the deeper problems of identity and alienation that trouble him.... Underneath all the conflicting images of the Indian one fundamental truth emerges-the white man knows that he is an alien and he knows that North America is Indian-and he will never let go of the Indian image because he thinks that by some clever manipulation he can achieve an authenticity that cannot ever be his.

—Vine Deloria, Jr., “American Fantasy” 
